\title{
The relationship between perceived freedom, leisure involvement, and happiness of individuals participating in physical activities
}

Authors' Contribution: A Study Design

B Data Collection

C Statistical Analysis

D Data Interpretation

E Manuscript Preparation

F Literature Search

G Funds Collection

\author{
Emrah Serdar ${ }^{1}$ ABCDEF, Duygu Harmandar Demirel ${ }^{2}$ ABCDEF \\ ${ }^{1}$ Faculty of Sports Science, Istanbul University-Cerrahpaşa, Turkey \\ ${ }^{2}$ Ahmet Keleşoğlu Faculty of Education, Necmettin Erbakan University, \\ Meram/Konya, Turkey
}

\section{abstract}

Background: This study is aimed to determine the relationship between the perceived freedom, involvement and happiness of individuals participating in physical activities.

Material and methods: The sample of the study consisted of 523 members. The Perceived Freedom in Leisure Scale, the Leisure Involvement Scale and the Oxford Happiness Questionnaire Short Form were used as data collection tools. In analysing the data, independent t-test, ANOVA, MANOVA and Pearson Correlation analysis were used.

Results: Independent t-Test results determined a significant difference between OHQ-SF scores according to the participants' gender. MANOVA analysis result showed that the main effect of the gender variable on the sub-dimensions of LIS was significant, and there was a difference in all sub-dimensions. The main effect of marital status on the sub-dimensions of LIS was significant, while there was a positive and low-level relationship between age and OHQ-SF.

Conclusions: The levels of OHQ-SF, PFLS-25 and LIS differ depending on the individuals' socio-demographic characteristics. Moreover, there was a positive and low level of relationship between OHQ-SF and PFLS25 and LIS, and a positive and low level of correlation between PFLS-25 and LIS.

Key words: Oxford happiness, perceived freedom in leisure, leisure involvement, physical activities.

\section{article details}

Article statistics: Word count: 3,681; Tables: 5; Figures: 0; References: 69

Received: July 2021; Accepted: November 2021; Published: December 2021

Full-text PDF: http://www.balticsportscience.com

Copyright $\odot$ Gdansk University of Physical Education and Sport, Poland

Indexation: Celdes, Clarivate Analytics Emerging Sources Citation Index (ESCI), CNKI Scholar (China National Knowledge Infrastructure), CNPIEC, DOAJ, EBSCO - Central \& Eastern European Academic Source, EBSCO - SPORTDiscus, EBSCO Discovery Service, Google Scholar, Index Copernicus, J-Gate, Naviga (Softweco, Primo Central (ExLibris), ProQuest - Family Health, ProQuest - Health \& Medical Complete, ProQuest - Illustrata: Health Sciences, ProQuest Nursing \& Allied Health Source, Summon (Serials Solutions/ProQuest, TDOne (TDNet), Ulrich's Periodicals Directory/ ulrichsweb, WorldCat (OCLC)

Funding: This research received no specific grant from any funding agency in the public, commercial, or not-for-profit sectors. Authors have declared that no competing interest exists.

is an open access article distributed under the terms of the Creative Commons Attribution-Non-Commercial-NoDerivatives 4.0 International (https://creativecommons.org/licenses/by-nc-nd/4.0/), which permits use, distribution, and reproduction in any medium, provided the original work is properly cited, the use is non-commercial and is otherwise in compliance with the license. 


\section{INTRODUCTION}

According to the International Sociological Association (ISA), leisure includes a series of activities in which individuals participate voluntarily after they can relax, rejoice and improve their knowledge or receive non-profit education and meet their professional, family and social needs [1, 2]. Kraus [3] has defined leisure as the time in which individuals choose their activities freely, satisfy their feelings of emotion, pleasure and fun, and realize their potential [4]. Beard and Ragheb [5] have stated that leisure time plays a dynamic role in individuals' lives, and it can be useful to know how satisfaction gains resulting from leisure participation are related to personal and social harmony, mental health and general happiness [6]. Again, it is stated that leisure activities have positive effects on individuals' social relations, physical and psychological health [7, 8]. Iso-Ahola [9], on the other hand, has stated that effective leisure has two conditions: the perception of freedom and intrinsic motivation, and the most important of these is the perception of freedom [10]. Moreover, perceived freedom has emerged as an important dimension for understanding leisure behaviour [11].

Neulinger's [12] paradigm is among the first to conceptualize leisure as a psychological experience that uses perceived freedom-constraints and intrinsic-extrinsic motivation as the main constructs that define it. Paradigms are "pure-leisure" (freely engaged and done for their own sake), "leisure-work" (freely engaged but providing satisfaction only in terms of its results or returns), "pure work" (obstructed but purely internal provides rewards) and "pure job" (satisfaction occurs only through results or returns, while under constraints) [13]. Neulinger $[12,13]$ has evaluated the first two categories, which are characterized by the basic criterion of perceived freedom, as possible situations in which leisure occurs. In this context, perceived freedom in leisure is explained as a cognitive motivational structure that includes individuals' perceptions about leisure activities related to their choices [14]. Individuals who believe they have more freedom in their leisure time experience tend to show higher levels of competence, locus of control, intrinsic motivation, and gameplay [15, 16]. On the other hand, individuals who have a low level of perceived freedom in leisure time can perceive desperation and rely on others to find leisure time opportunities $[17,18]$.

The concept of involvement is defined by Rothschild [19] as a state of motivation, arousal or interest [20]. Kyle and Chick [21] conceptualized involvement as "Personal Involvement" that activity carries for a person [22]. Involvement has emerged as an important concept for understanding leisure time behaviours of individuals [23]. In this context, leisure time involvement refers to individuals' emotional interest in certain leisure activities, leisure time environments, leisure facilities and products [24-26]. In other words, leisure involvement refers to a long-term and continuous involvement with multifaceted self-awareness and motivation [27]. Ragheb [28] defines leisure time as positive feelings about an activity that one believes can add value to their life [29]. Kyle et al. [30] divided leisure time involvement levels into five groups: attractiveness, giving importance, self-expression, social interaction, and identification. Attractiveness refers to the degree to which an activity is evaluated as enjoyable, fun and interesting for an individual [22, 31]. Self-expression refers to the degree to which a certain activity has a symbolic meaning for an individual [22]. Giving importance is explained as to how much leisure time activity plays a central role in individuals' lives [31-33]. While social interaction refers to the social bonds that connect individuals to a leisure activity. Identification is explained as the state of self-confirmation by individuals through leisure time activities [30, 34].

Happiness is conceptualized as an internal state obtained by individuals thinking about their life experiences and evaluating it as well [35,36]. According to Diener [37], happiness is explained as the emotional evaluation of well-being, which requires the superiority of positive effects over negative effects [38]. Happiness, which is also defined as positive impact 
and subjective well-being, is also expressed as a product of participation, environment and attitude [39, 40]. In the happiness theory, it is accepted that judgments of happiness are subjective in nature and inevitably affect ratings, and emotional self-evaluations are involved in all aspects [41, 42]. Veenhoven [43] mentions that happiness has two meanings [44]. The first of them is objectively called happiness and has components such as good living conditions, peace, tranquillity, and freedom. The second is defined as happiness in a subjective sense and is related to subjective happiness, a spiritual state and emotions [43, 44].

When the studies in the literature are examined, it was seen that leisure involvement and leisure benefit [27, 38], happiness [38, 45], leisure constraints [46], motivation [47], leisure satisfaction [48], and job satisfaction [29] are discussed. Moreover, perceived freedom in leisure and leisure benefit 49], job satisfaction [50], leisure satisfaction [18, 51, 52], work stress [10], leisure constraints [53], leisure perception [54], leisure attitude [18] are examined together. Finally, happiness and leisure [36, 55, 56, 57], leisure satisfaction $[41,58,59,60]$ are examined together. It is thought that for individuals who participate in physical activities, to use their leisure, perceived freedom levels as a result of the activities they participate in, and the level of interest in the activity they participate in, as well as the happiness levels they achieve, are important. From this point of view, this study aimed to determine the relationship between the perceived freedom, involvement and happiness of individuals participating in physical activities.

\section{MATERIAL AND METHODS}

Research Model: According to the aim of the study, the relational scanning model was used in the research. In the relational survey model, questions such as the degree of change between variables or the level of the examined situation were clarified with relational survey patterns [61].

Research Group: The sample of the study consisted of 523 members, 320 male (Meanage $=33.29 \pm 10.65)$ and 203 female (Meanage $=31.22 \pm 11.69)$, who were members of a private fitness centre in Istanbul and selected by a purposeful sampling method. $47.6 \%$ of the participants were "university graduates", 58.3\% were "married", $44.7 \%$ of them had a "normal" welfare status; $43.4 \%$ of the participants used the fitness centre between "1-2 days" per week, while $32.5 \%$ of them had "6-10 hours" of leisure time per week.

\section{DATA COLLECTION TOOLS}

Personal Information Form: The "Personal Information Form" was prepared by the researcher to collect information about the individuals who participated in the study. It consisted of questions regarding gender, age, marital status, frequency of going to the fitness centre, and weekly leisure time.

The Perceived Freedom in Leisure Scale-25 (PFLS-25): The Perceived Freedom in Leisure Scale-25 (PFLS-25), which was developed by Witt and Ellis [62] to determine the perceived competence, perceived control and perceived intrinsic motivation of individuals in leisure, was first adapted to Turkish by Lapa and Ağyar [63]; the later construct validity of the scale as tested by Lapa and Kaas [64] was used. The scale has 25 items and a single subdimension, and the reliability coefficient was found to be 0.93 . In this study, the reliability coefficient was determined as 0.92. Items in the scale were scored as (1) Strongly Disagree to (5) Strongly Agree.

Leisure Involvement Scale (LIS): The "Leisure Involvement Scale (LIS)", which was developed by Kyle et al. [30] to determine the level of individuals' involvement in leisure activities and adapted to Turkish by Gürbüz et al. [65] was used. The scale consists of 5 sub-dimensions 
and 15 items: "Attractiveness" (3 Items), "Giving Importance" (3 Items), "Social Interaction" (3 Items), "Identification" (3 Items) and "Self-Expression" (3 Items). The internal consistency coefficient of the scale was determined as 0.89 . The internal consistency coefficients for sub-dimensions determined as respectively, 0.80 for Attractiveness sub-dimension, 0.66 for Giving importance sub-dimension, 0.70 for Social Interaction sub-dimension, 0.58 for Identification sub-dimension and 0.67 for Self-Expression sub-dimension. In our study, the internal consistency coefficient for the sub-dimensions determined as 0.95, 0.96, 0.95, 0.95 and 0.96, respectively. Items in the scale were scored as (1) Strongly Disagree to (5) Strongly Agree.

Oxford Happiness Questionnaire-Short Form (OHQ-SF): To determine the individuals' happiness levels, "Oxford Happiness Questionnaire Short Form (OHQ-SF)", developed by Hills and Argyle [66] and adapted into Turkish by Doğan and Çötok [67], was used. The scale consists of 7 items and a single sub-dimension, and the reliability coefficient was determined to be 0.85 . In this study, the reliability coefficient was found to be 0.77 . Items in the scale were scored as (1) Strongly agree to (5) Strongly agree.

\section{DATA ANALYSIS}

SPSS 20.0 package program was used to analyse the data. The percentage and frequency method was used to determine the distribution of the participants' personal information. In order to determine whether the data showed normal distribution, the skewness and kurtosis values were examined, and it was understood that the data showed normal distribution. In this context, in the analysis of the data Independent t-test, ANOVA, MANOVA and Pearson Correlation analyses were used.

\section{RESULTS}

When the mean scores of the participants in Table 1 were examined, the mean scores of OHQ-SF were determined as (3.24). The mean score of PFLS-25 was determined as (3.61). It was determined that the highest average of LIS sub-dimensions was in the "Attractiveness" (3.43) sub-dimension, and the lowest average was "Self-expression" (2.27).

Table 1. Distribution of scale scores

\begin{tabular}{|c|c|c|c|c|c|c|c|}
\hline \multicolumn{2}{|r|}{ Sub-dimensions } & Items & $\mathrm{n}$ & Mean & $\mathrm{Sd}$ & Skewness & Kurtosis \\
\hline OHQ-SF & Oxford Happiness & 7 & 523 & 3.24 & 0.78 & 0.12 & 0.23 \\
\hline PFLS-25 & Perceived Freedom in Leisure & 25 & 523 & 3.61 & 0.70 & -0.29 & 0.44 \\
\hline \multirow{5}{*}{ LIS } & Attractiveness & 3 & 523 & 3.43 & 0.99 & -0.50 & -0.29 \\
\hline & Giving importance & 3 & 523 & 3.34 & 1.00 & -0.38 & -0.46 \\
\hline & Social interaction & 3 & 523 & 3.40 & 0.95 & -0.50 & -0.20 \\
\hline & Identification & 3 & 523 & 3.42 & 0.93 & -0.42 & -0.14 \\
\hline & Self-expression & 3 & 523 & 2.27 & 0.66 & -0.40 & -0.25 \\
\hline
\end{tabular}

In Table 2, the analysis results were given according to the subjects' gender. According to the analysis results, a significant difference was found between the OHQ-SF scores according to the participants' gender $(t=-2.896$; $p<0.05)$. Happiness levels of females were found higher than of males. According to the independent t-Test results, there was no statistically significant difference between the PFLS-25 scores according to the participants' gender $(\mathrm{t}=-.298 ; \mathrm{p}>0.05)$. MANOVA analysis results showed that gender had a significant effect on the sub-dimensions of LIS $\left[\lambda=0.969, \mathrm{~F}_{(5,517)}=3.304 ; \mathrm{p}<0.05\right]$. The mean scores of the female participants were higher than the scores of the male in the sub-dimensions as "Attractiveness" [ $\left.F_{(1-521)}=9.519 ; \mathrm{p}<0.05\right]$, "Giving importance" $\left[\mathrm{F}_{(1-521)}=10.898 ; \mathrm{p}<0.05\right]$, 
"Social Interaction" $\left[\mathrm{F}_{(1-521)}=13.658 ; \mathrm{p}<0.05\right]$, "Identification" $\left[\mathrm{F}_{(1-521)}=13.095 ; \mathrm{p}<0.05\right]$ and "Self-expression" $\left[\mathrm{F}_{(1-521)}=14.140 ; \mathrm{p}<0.05\right]$.

Table 2. Analysis results of OHQ-SF, PFLS-25 and LIS scores according to gender of participants

\begin{tabular}{clcccc}
\multirow{2}{*}{\begin{tabular}{c}
\multirow{2}{*}{ Scales } \\
\cline { 3 - 6 }
\end{tabular}} & \multicolumn{2}{c}{ Male $(\mathrm{n}=320)$} & \multicolumn{2}{c}{ Female $(\mathrm{n}=203)$} \\
\cline { 3 - 6 } OHQ-SF & Oxford Happiness & Mean & $\mathrm{Sd}$ & Mean & $\mathrm{Sd}$ \\
\hline PFLS-25 & Perceived Freedom in Leisure & 3.16 & 0.75 & 3.36 & 0.80 \\
\hline \multirow{2}{*}{ LIS } & Attractiveness & 3.61 & 0.70 & 3.63 & 0.69 \\
& Giving importance & 3.23 & 1.04 & 3.60 & 0.87 \\
& Social interaction & 3.31 & 1.03 & 3.52 & 0.93 \\
& Identification & 3.30 & 0.99 & 3.62 & 0.84 \\
& Self-expression & 2.19 & 0.68 & 2.41 & 0.81 \\
\hline
\end{tabular}

In Table 3, analysis results were given according to the subjects' marital status. There was no significant difference between OHQ-SF scores according to the individuals' marital status $(t=-.588 ; p>0.05)$. Similarly, it was determined that there was no statistically significant difference between the PFLS-25 scores according to the participants' marital status $(t=.825$; $\mathrm{p}>0.05$ ). The results of the MANOVA analysis showed that the main effect of marital status on the sub-dimensions of LIS was significant $\left[\lambda=0.973, F_{(5,517)}=2.909 ; p<0.05\right]$. A significant difference was found only in the "Attractiveness" sub-dimension $\left[F_{(1-521)}=6.180\right.$; $\mathrm{p}<0.05]$. It was determined that participants who were single had higher mean scores in the attractiveness sub-dimension.

Table 3. Analysis results of OHQ-SF, PFLS-25 and LIS scores according to marital status of participants

\begin{tabular}{clcccc}
\multirow{2}{*}{\begin{tabular}{c}
\multirow{2}{*}{ Scales } \\
\cline { 3 - 6 }
\end{tabular}} & & \multicolumn{2}{c}{ Single $(\mathrm{n}=218)$} & \multicolumn{2}{c}{ Married $(\mathrm{n}=305)$} \\
\cline { 3 - 6 } OHQ-SF & Oxford Happiness & Mean & $\mathrm{Sd}$ & $\mathrm{Mean}$ & $\mathrm{Sd}$ \\
\hline PFLS-25 & Perceived Freedom in Leisure & 3.21 & 0.76 & 3.25 & 0.79 \\
\hline \multirow{2}{*}{ LIS } & Attractiveness & 3.64 & 0.64 & 3.59 & 0.73 \\
& Giving importance & 3.56 & 0.96 & 3.34 & 1.00 \\
& Social interaction & 3.42 & 0.97 & 3.28 & 1.02 \\
& Identification & 3.46 & 0.97 & 3.41 & 0.94 \\
& Self-expression & 3.48 & 0.93 & 3.37 & 0.93 \\
\hline
\end{tabular}

Table 4 shows the results of the analysis according to the frequency of weekly fitness centre usage by the study participants. According to the analysis results, it was determined that there was a significant difference between the participants' OHQ-SF scores according to the frequency of weekly usage of the fitness centre $(f=.825 ; p<0.05)$. It was determined that the happiness levels of individuals who used the fitness centre for 5 days or more a week were higher. Similarly, a statistically significant difference was found between the PFLS25 scores $(\mathrm{f}=3.273 ; \mathrm{p}<0.05)$. Individuals who used the fitness centre $3-4$ days a week had higher perceived freedom levels in leisure. The results of the MANOVA analysis revealed that the main effect of participants' weekly fitness centre usage frequency on sub-dimensions of LIS was significant $\left[\lambda=0.961, \mathrm{~F}_{(10,1032)}=2.100 ; \mathrm{p}<0.05\right]$. At the sub-dimensions level, "Attractiveness" $\left[\mathrm{F}_{(2-520)}=5.694 ; \mathrm{p}<0.05\right]$, “Giving importance" $\left[\mathrm{F}_{(2-520)}=4.375 ; \mathrm{p}<0.05\right]$, "Social Interaction" $\left[\mathrm{F}_{(2-520)}=3.309 ; \mathrm{p}<0.05\right]$, "Identification" $\left[\mathrm{F}_{(2-520)}=3.525 ; \mathrm{p}<0.05\right]$ and "Self-Expression" $\left[\mathrm{F}_{(2-520)}=3.018 ; \mathrm{p}<0.05\right]$ sub-dimensions were found to be significantly different. In all sub-dimensions, it was determined that the sub-dimension scores of the 
individuals who used the fitness centre 3-4 days a week were higher than the sub-dimension scores of the other individuals.

Table 4. Analysis results of OHQ-SF, PFLS-25 and LIS scores according to the frequency of weekly fitness centre usage by the participants

\begin{tabular}{|c|c|c|c|c|c|c|c|}
\hline \multirow{2}{*}{ Scales } & & \multicolumn{2}{|c|}{$1-2$ days $(n=227)$} & \multicolumn{2}{|c|}{ 3-4 days $(n=190)$} & \multicolumn{2}{|c|}{$5-6$ days $(n=106)$} \\
\hline & & Mean & $S d$ & Mean & $\mathrm{Sd}$ & Mean & Sd \\
\hline OHQ-SF & Oxford Happiness & 3.26 & 0.74 & 3.18 & 0.83 & 3.48 & 0.77 \\
\hline PFLS-25 & Perceived Freedom in Leisure & 3.55 & 0.71 & 3.72 & 0.67 & 3.57 & 0.70 \\
\hline \multirow{5}{*}{ LIS } & Attractiveness & 3.32 & 1.00 & 3.62 & 0.88 & 3.33 & 1.09 \\
\hline & Giving importance & 3.24 & 1.00 & 3.51 & 0.96 & 3.25 & 1.05 \\
\hline & Social interaction & 3.39 & 0.95 & 3.56 & 0.88 & 3.28 & 1.05 \\
\hline & Identification & 3.37 & 0.89 & 3.55 & 0.88 & 3.27 & 1.07 \\
\hline & Self-expression & 2.25 & 0.65 & 2.36 & 0.61 & 2.16 & 0.75 \\
\hline
\end{tabular}

In Table 5, analysis results were given according to the scores of OHQ-SF, PFLS-25 and LIS according to the participants' ages. According to the analysis results, it was determined that there was a positive and low-level relationship between the participants' ages and OHQ-SF. Moreover, it was determined that there was no statistically significant relationship between the participants' age and the PFLS-25 and LIS. A positive and low-level relationship was found between OHQ-SF and PFLS-25. Besides, there was a positive and low-level relationship between OHQ-SF and LIS, and a positive and low-level one between PFLS-25 and LIS.

Table 5. Analysis results according to age and OHQ-SF, PFLS-25 and LIS scores

\begin{tabular}{|c|c|c|c|c|c|c|c|c|}
\hline & Age & $\mathrm{F} 1$ & F2 & F3 & F4 & F5 & F6 & F7 \\
\hline Age & 1 & & & & & & & \\
\hline F1 & $.125^{* *}$ & 1 & & & & & & \\
\hline F2 & -.031 & $.206 * *$ & 1 & & & & & \\
\hline F3 & -.066 & $.220 * *$ & $.267 * *$ & 1 & & & & \\
\hline F4 & -.049 & $.243^{* *}$ & $.237 * *$ & $.737 * *$ & 1 & & & \\
\hline F5 & .015 & $.246^{* *}$ & $.271^{* *}$ & $.838^{* *}$ & $.706 *$ & 1 & & \\
\hline F6 & -.047 & $.251^{* *}$ & $.293 * *$ & $.831^{* *}$ & $.810 * *$ & $.825^{* *}$ & 1 & \\
\hline F7 & -.031 & $.237^{* *}$ & $.269 * *$ & $.792^{* *}$ & $.698 * *$ & $.790 * *$ & $.822 *$ & 1 \\
\hline
\end{tabular}

$(\mathrm{P}<0.01)^{* *}(\mathrm{p}<0.05) * \mathrm{~F} 1=\mathrm{OHQ}-\mathrm{SF}, \mathrm{F} 2=\mathrm{PFLS}-25, \mathrm{~F} 3=$ Attractiveness, F4=Giving Importance, F5=Social Interaction, $\mathrm{F} 6=$ Identification, $\mathrm{F} 7=$ Self-Expression

\section{DISCUSSION}

This research aimed to determine the relationship between the perceived freedom, involvement and happiness of individuals participating in physical activities. In this context, the obtained results are discussed and interpreted in this section.

A significant difference was determined between the happiness levels of female participants and male participants in favour of the female participants. In other words, it can be said that females who participate in physical activity gain more happiness from the activity than males. These results are parallel with the results of a study conducted by Chen et al. [38], while there is a conflict between results of the study conducted by Serdar [55] and Aydin [34]. Although the levels of freedom perceived by females in leisure were higher than males, no significant difference was found. This can be explained as the gender variable was not an important factor in determining the level of freedom that individuals perceive at the end 
of the activity. In this context, while it was parallel with the results of the studies conducted by Serdar [49], Demirel et al. [53] and Harmandar Demirel et al. [54], there was a conflict between the results of the study conducted by Kara [68] and Lapa [69].

It was determined that the participants' gender had a significant effect on their leisure involvement. At the level of sub-dimensions, the mean scores of females in the subdimensions of "Attractiveness", "Giving Importance", "Social Interaction", "Identification" and "Self-expression" were found to be higher than the scores of males. In this context, it can be said that females participating in physical activity had higher levels of involvement in the activity in which they participate than males. The results of studies conducted by Chen et al. [38], Ekinci and Yalçın [7], Chang [8], and Demirel [45] were parallel with the results of this study.

There was no statistically significant difference between the participants' happiness according to their marital status. In other words, it can be said that the happiness levels of single and married as a result of the physical activities in which they participate did not differ, and marital status was not an important factor in determining their happiness levels. This was in line with the results of the studies conducted by Demirel [45], while it did not coincide with the results of the studies conducted by Aydın [34]. Although the mean scores of single participants were high, there was no statistically significant difference between the levels of perceived freedom in leisure according to the participants' marital status. Whether individuals were married or single can be interpreted as not an important variable in determining their perceived freedom level in leisure. Besides, there was a significant difference only in the "attractiveness" sub-dimension between married and single participants' leisure involvement levels. In other words, it was determined that the attractiveness sub-dimension scores of the single individuals were higher than the married participants. This can be explained by the fact that single participants find the activities more attractive. As a result, the results of the study conducted by Demirel [45] did not match the results of this study.

It was determined that there was a difference between the participants' happiness levels according to the frequency of fitness centre usage, and the participants who went to the fitness centre 5 days or more per week achieved a higher level of happiness compared to other individuals. In other words, physical activities in which individuals participate following their interests and desires contribute to their continuity towards activity and thus to their happiness. In the study conducted by Aydın [34], it was stated that there was no difference between the happiness levels of the participants according to the frequency of the fitness centre usage. Aydın's [34] did not match the results of this study. A statistically significant difference was found between the perceived freedom levels of the participants according to the frequency of the weekly fitness centre usage. The perceived freedom levels of individuals who went to the fitness centre 3-4 days a week were higher than other individuals. In other words, individuals who participated in physical activity 3-4 days a week had higher perceptions of freedom and intrinsic motivation levels than other individuals. The main effect of the frequency of the weekly fitness centre usage on the level of individuals' involvement was significant, and there was a significant difference in all sub-dimensions. The level of involvement of the participants who went to the fitness centre for 3-4 days a week were higher than that of other individuals. In other words, the type of physical activity that the participants participate in meets their expectations and wishes. The results of the study conducted by Aydın [34] showed parallelism with the results of this study.

A positive and low-level relationship was found between the participants' age and their level of happiness. In other words, as the participants' age increased, their happiness also increased. The results of Demirel's research [45] were not in line with the results of 
this research. It was determined that there was no statistically significant relationship between the ages of the individuals and their leisure involvement. In the study conducted by Ekinci and Yalçın [7] on leisure Involvement of individuals aged 40 and over, no difference between the individuals' leisure involvement according to their ages was determined. It was found that there was no significant relationship between age and the perceived freedom in leisure. Finally, it was found that there was a positive and low-level relationship between OHQ-SF and PFLS-25. Moreover, it was determined that there was a positive and low-level relationship between OHQ-SF and LIS, and a positive and low-level relationship between PFLS-25 and LIS.

As a result, as individuals' perceived freedom in leisure increased, their happiness increased. This situation can be interpreted as the benefits gained by individuals as a result of using their leisure in line with their wishes and desires positively affect their happiness levels. It was observed that as the leisure time interest of the participants increased, their happiness increased. The results of the study conducted by Demirel [45] are parallel with the results of this study. Moreover, in the study conducted by Chen et al. [38], it was stated that leisure involvement and its benefits predicted happiness in a positive way. It was observed that as individuals' perceived freedom in leisure increase, their involvement also increased. When individuals gain pleasure, satisfaction or benefit from the activity they participate in line with their preferences, the perceived freedom in leisure increased. In parallel with this situation, it can be explained that the individuals who reach the goal they want to reach as a result of the activity may have higher involvement at the point of participation or preference in the next activity.

\section{CONCLUSIONS}

It was determined that females' leisure involvement and happiness were higher than those of males. It was observed that the leisure involvement of single participants was higher than married participants. It was determined that as the age of individuals increased, their happiness increased. Besides, it was determined that there was no relationship between age and the perceived freedom in leisure and leisure involvement. Finally, it was found that there was a positive and low-level relationship between OHQ-SF and PFLS-25. Moreover, it was determined that there was a positive and low-level relationship between OHQ-SF and LIS, and a positive and low-level relationship between PFLS-25 and LIS.

\section{REFERENCES}

[1] Beenackers MA, Kamphuis C, Giskes K, et al. Socioeconomic inequalities in occupational, leisure-time, and transport related physical activity among European adults: A systematic review. Int J Behav Nutr Phys Act. 2012;9:116-139. https://doi.org/10.1186/1479-5868-9-116

[2] Sedighi S, Daraie M, Babazadeh M, Qarabaghi H. Activities through which Young spend leisure time in hamadan: Effects of personal values and attitudes. Mediter J Soc Sci. 2016;7(1):74-78. https://doi.org/10.5901/mjss.2016. v7n1s1p74

[3] Kraus RG. Leisure in a changing America: Multicultural perspectives. Macmillan College. Publishing Company; 1994 .

[4] Gürbüz B, Öncü E, Emir E. The Turkish adaptation of leisure facilitator scale: A validity and reliability study. Phys Educ Student. 2019;23(2):64-69. https://doi.org/10.15561/20755279.2019.0202

[5] Beard JG, Ragheb MG. Measuring leisure satisfaction. J Leisure Res. 1980;12:20-33. https://doi.org/10.1080/0022 2216.1980.11969416

[6] Spiers A, Walker GJ. The effects of ethnicity and leisure satisfaction on happiness, peacefulness and quality of life. Leisure Sci. 2008;31:84-99. https://doi.org/10.1080/01490400802558277

[7] Ekinci NE, Yalcın H. Leisure involvement level of 40 and over aged individuals. J Educat Iss. 2019;5(2):170-181. https://doi.org/10.5296/jei.v5i2.15683

[8] Chang HH. Gender differences in leisure involvement and flow experience in professional extreme sport activities. World Leisure J. 2017;59(2):124-139. https://doi.org/10.1080/16078055.2016.1166152

[9] Iso-Ahola SE. The social psychology of leisure and recreation. Dubuque, IA: WC. C. Brown; 1980.

[10] Yaşartürk F, Yılmaz H. Rekreatif etkinliklere katılan kamu personellerinin iş stresi ve serbest zamanda algılanan özgürlük düzeyleri arasındaki ilişkinin incelenmesi [Examination of the relationship between job stress and perceived freedom in leisure time of civil servants participating in recreational activities]. Manas Sosyal Araştırmalar Dergisi, 2019;8(Ek Sayı 1):1361-1371. https://doi.org/10.33206/mjss.499731 Turkish. 
[11] Wu HC, Liu A, Wang CH. Taiwanese University students' perceived freedom and participation in leisure. Ann Leisure Res. 2010;13(4):679-700. https://doi.org/10.1080/11745398.2010.9686870

[12] Neulinger J. The psychology of leisure. Springfield, IL: Charles C. Thomas; 1974.

[13] Webb E, Karlis G. Theoretical developments in leisure studies: A look at perceived freedom and intrinsic motivation. Loisir et Société / Society and Leisure. 2017;40(2):268-283. https://doi.org/10.1080/07053436.2017.1328790

[14] Ağyar E. Contribution of perceived freedom and leisure satisfaction to life satisfaction in a sample Turkish woman Soc Indic Res. 2014;116:1-15. https://doi.org/10.1007/s11205-013-0268-0

[15] Guinn B, Semper T, Jorgensen L. Perceived leisure freedom and activity involvement among Mexican American adolescents. Hispanic J Behav Sci. 1996;18:356-366. https://doi.org/10.1177/07399863960183006

[16] Janke MC, Carpenter G, Payne LL, Stockard J. The role of life experiences on perceptions of leisure during adulthood: A longitudinal analysis. Leisure Sci. 2011;33(1):52-69. https://doi.org/10.1080/01490400.2011.533108

[17] Ellis GD, Witt PA. (1986). The leisure diagnostic battery: Past, present, and future. Therap Recr J. 1986;20:31-47.

[18] Siegenthaler KL, O’Dell I. Leisure Attitude, Leisure Satisfaction, and Perceived Freedom in Leisure Within Family Dyads. Leisure Sci. 2000;22:281-296. https://doi.org/10.1080/01490409950202302

[19] Rothschild ML. Perspectives on involvement: Current problems and future directions. Adva Consum Res. 1984;11:216-217.

[20] Alexandris K, Kouthouris C, Funk D, Tziouma O. The use of negotiation strategies among recreational participants with different involvement levels: the case of recreational swimmers. Leisure Stud. 2013;32(3):299-317. https://doi org/10.1080/02614367.2012.660189

[21] Kyle G, Chick G. Enduring leisure involvement: The importance of personal relationships. Leisure Stud. 2004;23(3):243266. https://doi.org/10.1080/0261436042000251996

[22] Alexandris K, Douka S, Balaska P. Involvement with active leisure participation: does service quality have a role? Manag Leisure. 2012;17(1):54-66, https://doi.org/10.1080/13606719.2011.638203

[23] Wiley, C.G.E., Shaw, S.M., Havitz, M.E. (2000). Men's and Women's involvement in sports: an examination of the gendered aspects of leisure involvement, Leisure Sciences, 22(1), 19-31. https://doi.org/10.1080/014904000272939

[24] Cheng TM, Hung SH, Chen MT. The influence of leisure involvement on flow experience during hiking activity: using psychological commitment as a mediate variable. Asia Pacific J Tourism Res. 2016;21(1):1-19. https://doi.org/10.1 080/10941665.2014.1002507

[25] Gahwiler P, Havitz ME. Toward a relational understanding of leisure social worlds, involvement, psychological commitment, and behavioral loyalty. Leisure Sci. 1998;20(1):1-23. https://doi.org/10.1080/01490409809512262

[26] Kim SS, Scott DL, Crompton JL. An exploration of the relationships among social psychological involvement, behavior involvement, commitment, and future intentions in the context of bird watching. J Leisure Res. 1997;29(3):320-341. https://doi.org/10.1080/00222216.1997.11949799

[27] Ho TS. An exploration of relationship among leisure involvement, leisure benefits, quality of life, and training effects of collegiate athletes. Int J Organization Innov. 2018;10(4):327-344.

[28] Ragheb MG. Assessment of leisure and recreation involvement. Enumclaw: Idyll Arbor.United States; 2002.

[29] Suhartanto D, Dean D, Sumarjan N, Kartika OS, Setiawati L. Leisure involvement, job satisfaction, and service performance among frontline restaurant employees. J Qual Assur Hospital Tourism. 2019;20(4):387-404. https:// doi.org/10.1080/1528008X.2018.1543631

[30] Kyle GT, Absher J, Norman W, Hammit W, Jodice L. Modified involvement scale. Leisure Stud. 2007;26(4):398-427. https://doi.org/10.1080/02614360600896668

[31] McIntyre N, Pigram JJ. Recreation specialization reexamined: The case of vehicle-based campers. Leisure Sci. 1992;14:3-15. https://doi.org/10.1080/01490409209513153

[32] Jun J, Kyle ., Graefe A, Manning R. An identity-based conceptualization of recreation specialization. J Leisure Res. 2015;47:425-443. https://doi.org/10.1080/00222216.2015.11950369

[33] Matsumoto H, Sato S, Asada A, Chiashi K. (2018) Exploring the relationship among leisure engagement, affective and cognitive leisure involvement, and subjective happiness: A mediating role of leisure satisfaction. World Leisure J. 2018;60(2):111-126. https://doi.org/10.1080/16078055.2018.1444669

[34] Aydın I. Fitnes katılımcılarının rekreasyonel etkinliklere yönelik ilgilenim ve mutluluk düzeylerinin belirlenmesi [Determining the interest and happiness levels of fitness participants towards recreational activities]. Gazi Üniversitesi, Sağlık Bilimleri Enstitüsü; 2016. Turkish.

[35] Csikszentmihalyi M. Flow: The psychology of optimal experience. New York: Harper Collins; 1990.

[36] Lepp A. Correlating leisure and happiness: the relationship between the leisure experience Battery and the satisfaction with life scale. Ann Leisure Res. 2018;21(2):246-252. https://doi.org/10.1080/11745398.2017.1325759

[37] Diener E. Subjective well-being. Psychol Bull. 1984;95(3):542-575. https://doi.org/10.1037/0033-2909.95.3.542

[38] Chen CC, Cheng CH, Lin SY. The relationship among leisure involvement, leisure benefits and happiness of elementary schoolteachers in Tainan country. Int ResEduc. 2013;1(1):29-51. https://doi.org/10.5296/ire.v1i1.3970

[39] Seligman MEP. Authentic happiness. New York: Free Press; 2002.

[40] Bailey AW, Fernando IK. Routine and project-based leisure, happiness, and meaning in life. J Leisure Res. 2012;44(2):139-154. https://doi.org/10.1080/00222216.2012.11950259

[41] Liu H, Chen X, Zhang H. Leisure satisfaction and happiness: The moderating role of religion. Leisure Stud. 2020;40(2):212-226. https://doi.org/10.1080/02614367.2020.1808051

[42] Myers DG, Diener E. Who is happy? Psychol Sci. 1995; 6(1):10-19. https://doi.org/10.1111/j.1467-9280.1995.tb00298.x

[43] Veenhoven R. Life is getting better: societal evolution ve fit with human nature. Soc Indicat Res. 2010;97(1):105-122 https://doi.org/10.1007/s11205-009-9556-0

[44] Honca AA, Koç MC. The role of course-leisure conflict on happiness. Int J Educ Technol Scient Res. 2020;5(13):14211444. https://doi.org/10.35826/ijetsar.257 
[45] Demirel M. Leisure involvement and happiness levels of individuals having fitness center membership. J Educ earning. 2019;8(6):140-149. https://doi.org/10.5539/jel.v8n6p140

[46] Serdar E. Serbest zaman engelleri ile ilgilenim arasındaki ilişki: Fitness merkezi katılımcıları üzerine bir araştırma [The relationship between leisure time barriers and involvement: A study on fitness center participants]. Spor Bilimleri Araştırmaları ergisi. 2021;6(1):49-61. https://doi.org/10.25307/jssr.889333. Turkish.

[47] Kyle GT, Absher J , Hammit WE, Cavin J. An examination of the motivation-involvement relationship. Leisure Sci. 2006;28:467-485. https://doi.org/10.1080/01490400600851320

[48] Chen YC, Li RH, Chen SH. Relationship among adolescents' leisure motivation, leisure involvement and leisure satisfaction: A structural equation model. Social Indicators Res. 2013;110:1187-1199. https://doi.org/10.1007/ s11205-011-9979-2

[49] Serdar E. The effects of perceived freedom in leisure on leisure benefits: Students of the faculty of sports science. Turkish J Sport Exerc. 2020;22(2):208-213.

[50] Serdar E. The relationship between perceived freedom in leisure and job satisfaction: A research on private sector employees. Int J Sport Culture Sci. 2021;9(1):127-136.

[51] Gökçe H, Uygurtaş M, Morca Ş. Düzenli fiziksel etkinliklere katılan bireylerin serbest zaman doyumu serbest zamanlarda algilanan özgürlük ve sosyal görünüş kaygi düzeyleri [Leisure satisfaction, perceived freedom and social appearance anxiety levels of individuals participating in regular physical activities]. OPUS Uluslararası Toplum Araştırmaları ergisi.2020;15(26):4408-4420. https://doi.org/10.26466/opus.650826. Turkish.

[52] Munchua MM, Lesage M, Reddon JR, Badham T . Motivation, satisfaction and perceived freedom: A tri-dimensional model of leisure among young offenders. J Offend Rehabil. 2003;38(1):53-64. https://doi.org/10.1300/J076v38n01_05

[53] Demirel M, Harmandar Demirel D, Serdar E. Constraints and perceived freedom levels in the leisure of unıversity students. J Hum Sci. 2017;14(1):789-795. https://doi.org/10.14687/jhs.v14i1.4340

[54] Harmandar Demirel D, Demirel M, Serdar E. University students' opinions of the meaning of leisure and their perceived freedom in leisure. J Hum Sci. 2017;14(1):796-802. https://doi.org/10.14687/jhs.v14i1.4340

[55] Serdar E. Serbest zaman fayda ile mutluluk arasındaki ilişki: Spor bilimleri fakültesi öğrencileri [The relationship between leisure time benefit and happiness: students of faculty of sports sciences]. Turkish Studies Social.2020;15(5):2711-2721. https://doi.org/10.47356/TurkishStudies.44273. Turkish.

[56] Wei X. Huang SS, Stodolska M, Yu Y. Leisure time, leisure activities, and happiness in China. J Leisure Res. 2015;47(5):556-576. https://doi.org/10.18666/jlr-2015-v47-i5-6120

[57] Liu H, Da S. The relationships between leisure and happiness-A graphic elicitation method. Leisure Stud. 2020;39(1):111-130. https://doi.org/10.1080/02614367.2019.1575459

[58] Yıldız Y. Yağlı güreş sporcularının serbest zaman doyumları ile mutluluk düzeyleri ilişkisinin incelenmesi [Investigation of the relationship between leisure time satisfaction and happiness levels of oil wrestling athletes]. Akdeniz Spor Bilimleri Dergisi. 2020;3(2):346-355. https://doi.org/10.38021/asbid.834089 Turkish.

[59] Argan M, Argan TM, Dursun MD. Examining relationships among well-being, leisure satisfaction, life satisfaction and happiness. Int J Med Res Health Sci. 2018;7(4):49-59.

[60] Serdar E, Demirel M, Demirel DH, Donuk B. Üniversite öğrencilerinin serbest zaman doyum düzeyleri ile mutluluk düzeyleri arasındaki ilişki [The relationship between university students' leisure satisfaction levels and happiness levels]. Uluslararası Sosyal Bilimler Dergisi. 2018;5(28):429-438. https://doi.org/10.16990/SOBIDER.4412 Turkish.

[61] Gürbüz S, Şahin F. Sosyal Bilimlerde Araştırma Yöntemleri. Gözden Geçirilmiş ve Güncellenmiş 3. Basım [Research Methods in Social Sciences. Revised and Updated 3rd Edition]. Ankara: Seçkin Yayıncılık; 2016. Turkish.

[62] Witt PA, Ellis GD. Development of a short form to assess perceived freedom in leisure. J Leisure Res. 1985;17(3):225 223. https://doi.org/10.1080/00222216.1985.11969632

[63] Lapa TY, Ağyar E. Cross cultural adaptation of perceived freedom in leisure scale. World Appl Scie J. 2011;14(7):980-926.

[64] Lapa TY, Kaas ET. Serbest zamanda algılanan özgürlük ölçeği-25: Üniversite öğrencileri için yapı geçerliğinin sinanması [Scale of perceived freedom in leisure time-25: Testing construct validity for university students]. J Hum Sci. 2019;6(4):1071-1083. https://doi.org/10.14687/jhs.v16i4.5860 Turkish.

[65] Gürbüz B, Çimen Z, Aydın İ. Serbest zaman ilgilenim ölçeği Türkçe formu geçerlik ve güvenirlik çalışması [The validity and reliability study of the Turkish form of the leisure involvement scale]. In: III. Rekreasyon Araştırmalar Kongresi, 5/7 Kasım 2015. Eskişehir. https://doi.org/10.20493/bt.99023 Turkish.

[66] Hills P, Argyle M. The oxford happiness questionnaire: a compact scale for the measurement of psychological wellbeing. Personality and Individual Differences. 2002;33:1073-1082. https://doi.org/10.1016/S0191-8869(01)00213-6

[67] Doğan T, Çötok NA. Oxford mutluluk ölçeği kısa formunun türkçe uyarlaması geçerlik ve güvenirlik çalışması [The validity and reliability study of the Turkish adaptation of the Oxford happiness scale short form]. Türk Psikolojik Danışma ve Rehberlik Dergisi. 2011;4(36):165-172. Turkish.

[68] Kara FM. Internet addiction: relationship with perceived freedom in leisure, perception of boredom and sensation seeking. Higher Educ Stud. 2019;9(2):131-140. https://doi.org/10.5539/hes.v9n2p131

[69] Lapa TY. Life satisfaction, leisure satisfaction and perceived freedom of park recreation participation. Proc Soc Behav Sci. 2013;93:1985-1993. https://doi.org/10.1016/j.sbspro.2013.10.153

\section{Cite this article as:}

Serdar E, Harmandar Demirel D.

The relationship between perceived freedom, leisure involvement, and happiness of individuals participating in physical activities

Balt J Health Phys Act. 2021;Suppl(2):13-22.

doi: 10.29359/BJHPA.2021.Suppl.2.02 